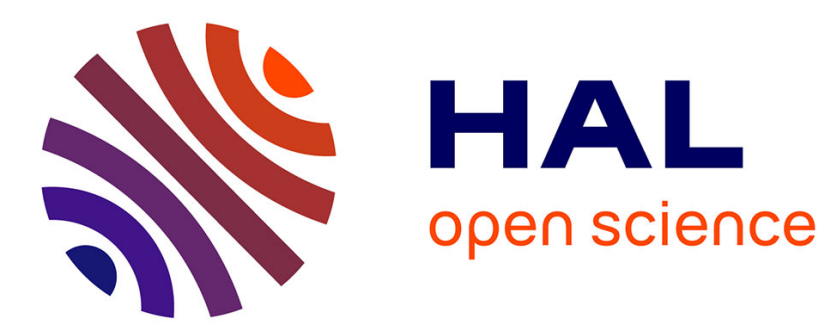

\title{
Rock magnetic investigation of possible sources of the Bangui magnetic anomaly
}

Mariane Ouabego, Yoann Quesnel, Pierre Rochette, François Demory, E. M. Fozing, T. Njanko, Jean-Claude Hippolyte, Pascal Affaton

\section{To cite this version:}

Mariane Ouabego, Yoann Quesnel, Pierre Rochette, François Demory, E. M. Fozing, et al.. Rock magnetic investigation of possible sources of the Bangui magnetic anomaly. Physics of the Earth and Planetary Interiors, 2013, 224, pp.11-20. 10.1016/j.pepi.2013.09.003 . hal-00933326v2

\section{HAL Id: hal-00933326 \\ https://hal.science/hal-00933326v2}

Submitted on 3 Mar 2014

HAL is a multi-disciplinary open access archive for the deposit and dissemination of scientific research documents, whether they are published or not. The documents may come from teaching and research institutions in France or abroad, or from public or private research centers.
L'archive ouverte pluridisciplinaire HAL, est destinée au dépôt et à la diffusion de documents scientifiques de niveau recherche, publiés ou non, émanant des établissements d'enseignement et de recherche français ou étrangers, des laboratoires publics ou privés. 
1 Rock magnetic investigation of possible sources of the Bangui magnetic anomaly

2

3 Ouabego $^{1,2}$, M., Quesnel ${ }^{2 *}$, Y., Rochette ${ }^{2}$, P., Demory ${ }^{2}$, F., Fozing ${ }^{3}$, E.M., Njanko ${ }^{3}$, T., 4 Hippolyte $^{2}$, J.-C., Affaton ${ }^{2}$, P.

5

61 - Geosciences Laboratory, Bangui University, Bangui, Centrafrican Republic

72 - Aix Marseille University, CNRS, IRD, CEREGE UM34, 13545 Aix-en-Provence, France

83 - Environmental Geology Laboratory, Dschang University, BP67, Dschang, Cameroon

$10 *$ Corresponding author :

11 Quesnel Yoann

12 Aix Marseille University, CNRS, IRD, CEREGE UM34, 13545 Aix-en-Provence, France

13 Ph.: +33442971590

14 Fax: +33442971595

15 Email: quesnel@ cerege.fr

17 Abstract

18 The Bangui Magnetic Anomaly (BMA) is the largest lithospheric magnetic field anomaly on

19 Earth at low latitudes. Previous studies investigated its geological source using constraints

20 from satellite and ground magnetic field measurements, as well as from surface magnetic

21 susceptibility measurements on rocks from the Panafrican Mobile Belt Zone (PMBZ). Here

22 we combine magnetic field data modelling and rock magnetic property measurements

23 (susceptibility and natural remanent magnetization, NRM) on many samples from this PMBZ

24 and the surrounding formations. It reveals that NRM is a significant component of the total 25 magnetization (Mt) of the BMA source, which reaches $4.3 \mathrm{~A} / \mathrm{m}$ with maximum thicknesses of 
2638 and $54 \mathrm{~km}$ beneath the western and eastern parts of the BMA. Only the isolated and

27 relatively thin banded iron formations and some migmatites show such Mt values. Thus we 28 suggest that the thick BMA source may be composed either by overlapped slices of such 29 metamorphic rocks, or by an iron-rich mafic source, or by a combination of these two 30 geological structures.

32 Keywords: Bangui magnetic anomaly, magnetization, geological source, modelling, banded 33 iron formation

\section{1 - Introduction}

Located in Centrafrican Republic, the Bangui Magnetic Anomaly (BMA) is one of the

37 largest lithospheric magnetic field anomaly on Earth, proeminent even at satellite altitude.

38 Different models have been proposed concerning its geological source. First, Regan and 39 Marsh (1982) suggested that a geological metamorphic process affected the entire crust of this 40 area during the Panafrican orogenesis, creating physical property contrasts between cratonic 41 regions and collisional belts. Ravat (1989) reinforced this model but suggested an additional 42 concentrated near-surface ore-like body (see also Ravat et al., 2002 and Langel and Hinze, 43 1998). This shallow body could correspond to the remains of an iron meteorite that fell in this 44 area during the Proterozoic era (Girdler et al., 1992; see also De et al., 1998 and Gorshkov et 45 al., 1996). Shock, thermal and/or chemical remanent magnetizations acquired during and after 46 the impact should have led to this highly-magnetized body. However, the impact hypothesis is 47 less suitable since the impactor material does not survive in significant amount in large craters 48 and thus cannot contribute to such a large magnetic anomaly (Koeberl, 1998). Furthermore no 49 shock remanent magnetization was observed on the rock samples from this area (Marsh, 50 1977). All these studies lack of constraints from magnetic property measurements on the 
51 corresponding rocks of this area. Here we combined rock magnetic measurements with

52 magnetic field anomaly modelling in order to investigate the possible source of the BMA.

53 In the first section, we summarize the geological context of the Centrafrican Republic,

54 especially in our studied area. Then, the BMA is introduced before the description of the

55 methods used. The next section details the results of magnetic property measurements and

56 BMA modelling over the studied area. The last section corresponds to a discussion on the

57 origin of the BMA, in the context of the general challenge involved in understanding large

58 and deep crustal anomalies using limited access to rock samples (e.g. Frost and Shive, 1986;

59 McEnroe et al., 2004, Rochette et al., 2005).

60

\section{2 - Geological context}

Central Africa is a key area of the African Plate since it constitutes the transition

63 between several old cratons (Figure 1a,b). This transition corresponds to several orogenic

64 belts such as the Panafrican belt (Nickles, 1952; Gérard, 1958; Black, 1966; Mestraud, 1971;

65 Alvarez, 1992, 1995; Rolin, 1995a,b). These belts are mobile zones of the Panafrican

66 Orogenesis at $600 \pm 100$ Ma (Kennedy, 1964; Rocci, 1965; Black, 1966). During this orogeny

67 plate movements closed oceanic areas leading to a belt of suture zones around the cratons in

68 the African regions of Gondwana. Our study area corresponds to Central Africa (Cameroon,

69 Centrafrican Republic, Chad and Congo) where the West-African and Congolese cratons are

70 separated by the Precambrian and Palaeozoic Oubanguides mobile zones (Figure 1b; Nickles,

71 1952; Gérard, 1958; Mestraud, 1971; Rolin, 1995b). Four geological domains are observed in

72 this area from the rare outcrops of the Archean terranes (about $3.5 \mathrm{Ga}$ ), the Eburnean

73 basement (2.4-2.2 Ga), the Neoproterozoic Panafrican cover (600 Ma) and the post-

74 Panafrican domain (Figure 1b,c). We focus our study on the southwestern part of the

75 Centrafrican Republic (Figure 1c) where the Oubanguides Panafrican Belt borders to the 
76 north the Congo craton. Syn- and post-glacial Marinoen sediments cover the Neoproterozoic

77 layers (Alvarez, 1999; Rolin, 1995a). A collision of an oceanic plate led to the presence of 78 metamorphic rocks that were sampled in this area (granulites, quartzites including Banded 79 Iron Formations (BIF), migmatites, orthogneisses, metabasalts, metasediments and 80 metaperidotites). All metamorphic grades are found from granulite to green schist. The whole 81 sequence was remobilized during the Panafrican orogenesis in nappes (formation 6 on Figure 82 1c) cut by N140 and N70-trending reverse faults (Figure 1c).

\section{3 - Geophysical context}

85 The western part of Central Africa shows one of the most prominent large-scale 86 magnetic anomaly on Earth: the Bangui magnetic anomaly (BMA; Figure 2). It corresponds 87 to a multipolar magnetic anomaly with a negative central lobe and two positive north and 88 south lobes (all are located south to the geomagnetic equator). It reaches about $800 \mathrm{~km}$ of N-S 89 wavelength and about $1000 \mathrm{nT}$ of amplitude at ground level. Its E-W axial extension also 90 reaches about $700 \mathrm{~km}$. Near the magnetic equator and in the sub-tropical zone, this is the 91 largest magnetic field anomaly. Here we use the anomaly field from the Magnetic Field model 927 (MF7; modified from the MF6 of Maus et al. (2008)) and downward continued to near the 93 Earth's surface $(2.5 \mathrm{~km}$ altitude - but this is considered as the 'satellite' signal in the 94 following). This model was derived using 2007-2010 magnetic data from the low-Earth orbit 95 CHAMP satellite. It resolves the crustal magnetic field anomalies with wavelengths larger 96 than $300 \mathrm{~km}$, for example the long-wavelength part of the BMA.

97 Ground magnetic data with a heterogeneous spatial resolution are also used in this 98 study. They were acquired by LeDonche and Godivier (1962) in Centrafrican Republic and 99 Chad (therefore no ground data were acquired at the southern lobe of the BMA). The 100 published maps are of the horizontal and vertical components of the total magnetic field, as 
101 well as the declination. To recover the total magnetic field (TF) anomaly, they substracted the 102 corresponding International Geomagnetic Reference Field (IGRF) model values from TF 103 values. We preferred to apply the Definitive Geomagnetic Reference Field (DGRF) model for 104 year 1960 (coefficients published in Finlay et al. (2010)) to derive the anomaly. It should be 105 noted that the TF anomaly values are close to the horizontal component anomaly values, as 106 expected for such low latitudes near the magnetic equator. The shape of the BMA differs 107 between the satellite data map and the ground data map. Indeed the latter reveals that the 108 western limit of the negative lobe of the satellite-derived anomaly is more heterogeneous at 109 ground level, with a local positive E-W elongated central anomaly nearby $\left(5^{\circ} \mathrm{N}, 17^{\circ} \mathrm{E}\right)$ 110 surrounding by local negative lobes south and north. Also, the E-W transition between the 111 central negative lobe and the northern positive one on the satellite-derived anomaly map is 112 about $0.3^{\circ}$ north than the same transition on the ground data map. This could indicate that the

113 main source body lies in the lower and middle crusts but that only several branches of this

114 source may really reach the upper crust. The negative lobe of the anomaly is more intense ($1151000 \mathrm{nT})$ on the ground data map than on the satellite anomaly map (-400 nT). It is also very 116 well correlated to a negative Bouguer gravimetric anomaly (data from Boukéké et al., 1995) 117 of $-125 \mathrm{mGal}$, indicating that the magnetization contrasts in the crust of this area may be 118 correlated to rock density contrasts from the same source region.

\section{4 - Methods}

\section{1 - Magnetic anomaly modelling}

To investigate the magnetic properties of the BMA source, we first used a modelling

123 method with the observed (ground as well as satellite-derived) magnetic and ground 124 gravimetric anomaly fields. The GM-SYS module of the GEOSOFT Oasis montaj software 125 was used. Gravity (Boukéké et al., 1995) and magnetic anomaly data along the NW-SE 
126 profiles shown on Figure 2 were considered. The geometry of the different geological layers

127 was constrained by 1) our own field observations (only near the western profile), 2) data from 128 previous geological maps (Rolin, 1995a), and 3) gravimetric and magnetic anomaly data. 129 Along the western profile, only the surface geology, ground magnetic and gravimetric data 130 really constrained the model, because the satellite-derived magnetic signal cannot reproduce 131 the short wavelengths observed at $2.5 \mathrm{~km}$ altitude. On the other hand, along the long eastern 132 profile, too few surface observations, probably representing very 'local' anomalies, exist to 133 consider the interpolated profile as a reasonable constraint. The directions of the remanent 134 magnetization vector of the source body were initially set to the 2011 and 1960 Bangui 135 magnetic field directions (Finlay et al., 2010) for modelling of satellite-derived and ground 136 data, respectively, but could vary if necessary during the inversion. The main aim of the 137 magnetic modelling was to infer the approximate range of total magnetization (Mt) of the 138 most magnetic formation beneath the BMA under the assumptions of induced magnetization 139 constraint and of a source model geometry able to fit the data whatever the location (western 140 or eastern profiles).

\section{2 - Sampling and rock magnetic measurements}

143 Over 50 large hand samples were obtained in the area of Figure 1c, during several 144 field missions. Sampling was designed to cover all lithologies and degrees of metamorphism 145 observed in this area. Petrography was determined using thin sections and, in some cases, X146 ray diffraction and chemical analysis. Low field magnetic susceptibility measurements were 147 carried out using SM30 susceptibility meter (ZH Instruments) for large samples and KLY2 148 susceptibility meter (AGICO) for small samples. Mass susceptibility $\chi$ was calculated using 149 the weight of the samples. For remanence and further rock magnetic measurements a first set 150 of samples (chosen to be representative of all lithologies) was completed by all samples with 
151 high susceptibility remaining in the collection: therefore the proportion of high susceptibility 152 samples is higher in the studied set. A total of 22 samples were thus fully investigated 153 magnetically. The Natural Remanent Magnetization (NRM) as well as saturation isothermal 154 remanent magnetization (SIRM) acquired at $1 \mathrm{~T}$ were measured using a spinner magnetometer 155 Minispin (Molspin) for large samples. In one case NRM was analysed by alternating field 156 demagnetization of a small sample using a superconducting rock magnetometer $760 \mathrm{R}(2 \mathrm{G}$ 157 enterprises). To characterize the magnetic minerals, thermomagnetic curves were acquired 158 using a MFK1 susceptibility meter (AGICO) with CS3 furnace (up to $650^{\circ} \mathrm{C}$ under argon 159 atmosphere), ambient temperature hysteresis measurements were performed with a vibrating 160 sample magnetometer Micromag 3900 (PMC) and its cryostat allowed measuring low temperature remanent magnetizations.

To compare with the magnetic properties of somewhat similar formations within the

163 Panafrican belt, we analysed susceptibility data from East Cameroon (Betaré Oya area, see 164 Figure 1a,b and Kankeu et al., 2009) as well as West Cameroon (after Njanko et al., 2012 and 165 ongoing magnetic anisotropy investigations of amphibolites and granitoids). Some samples 166 from W Cameroon were also measured for rock magnetic properties. Mass normalized rock magnetic measurements were used to evaluate in-situ Mt (in $\mathrm{A} / \mathrm{m}$ ) of the sampled formations using the following formula:

$$
\mathrm{Mt}=\rho(\mathrm{NRM}+\chi \mathrm{H})
$$

172 with $\rho$ the rock density $\left(2.7 \mathrm{~g} / \mathrm{cm}^{3}\right.$ for all rocks - a typical value for deep continental crust, 173 see Table 1 - except itabirites which were assumed to be $3.2 \mathrm{~g} / \mathrm{cm}^{3}$ ) and $\mathrm{H}$ the present 174 magnetic field intensity in Bangui $(33.6 \mu \mathrm{T}$, i.e. $26.8 \mathrm{~A} / \mathrm{m})$. Using field intensities at the dates 175 of the discussed magnetic field surveys makes negligible changes. This formula assumes that 
the induced and remanent magnetization components are colinear. Thus the resulting Mt

177 values computed with this equation will be maximum values. The Koenigsberger ratio $178(\mathrm{Q}=\mathrm{NRM} / \chi \mathrm{H})$ was also calculated.

$180 \quad 5$ - Results

\section{1 - Magnetic anomaly modelling}

The best models to represent the crustal magnetization and density variations beneath

183 the western and eastern BMA profiles are shown in Figure 3, and the parameters associated to

184 each layer are indicated in Table 1. For the most magnetic layer, using a shape similar than the one shown in Figure 3 but with different Mt value and associated thickness, a Mt of $4.3 \mathrm{~A} / \mathrm{m}$ indeed results in the best predictions of the data along both eastern and western profiles (see Table A1, Figures A1 and A2 in Supplementary Material). Only the $2.5 \mathrm{~km}$-altitude satellite-

188 derived magnetic data of the western profile and the ground magnetic data of the eastern 189 profile are not well predicted, as expected (see explanations in Section 4.1). The resulting 190 magnetization directions are similar to the input values. Similarly to the results of previous 191 BMA modelling studies, the superficial geological layers seem to be weakly magnetized.

192 With the selected shape, the top of the main magnetic source (layer 1) is $9 \mathrm{~km}$ deep beneath 193 the short western profile, $5 \mathrm{~km}$ deep beneath the long eastern profile. The total magnetic 194 thickness of this layer reaches 38 and $54 \mathrm{~km}$ beneath the western and eastern profiles, 195 respectively, even if significant lateral N-S thickness variations are observed beneath the western profile (Figure 3). This confirms that a huge amount of strongly magnetized rocks is

197 preserved in the crust of Centrafrican Republic, even beneath the sampled area near Bangui.

198 The gravity and magnetization contrasts in the models are similar to those of the model 199 proposed by Marsh (1977) and Regan and Marsh (1982) using satellite data only and 200 modelling the whole BMA. In particular, the magnetic source seems to be less dense (density 
201 contrast of about $-0.03 \mathrm{~g} / \mathrm{cm}^{3}$ ) than the deep non-magnetic surrounding rocks (mainly layer

2023 ), but denser $\left(>0.2 \mathrm{~g} / \mathrm{cm}^{3}\right)$ than the superficial non-magnetic formations (not considered in 203 model (b) of Figure 3). Note that a small relief of the Moho is necessary to completely 204 explain the shape of the gravity signal along the two profiles. Concerning the $4.3 \mathrm{~A} / \mathrm{m}$ 205 magnetization intensity for the most magnetic layer of the best model, using only induced 206 magnetization would require a rather unrealistically high $k$ of $1610^{-2}$ SI for the rocks of the 207 studied area. Therefore we arbitrarily separated this Mt value into a NRM of $4 \mathrm{~A} / \mathrm{m}$ and a 208 volumic susceptibility $k$ of $10^{-2}$ SI (Table 1 ).

\section{2 - Magnetic property measurements}

Table 2 shows the magnetic properties of the 22 studied samples. Most of our strongly

212 magnetic samples have Koenigsberger ratios (Q) larger than 1 (minimum values 0.3),

213 stressing the importance of not relying only on susceptibility measurements. Only two 214 samples corresponding to migmatite (8576) and itabirite (8603), have Mt over $4.3 \mathrm{~A} / \mathrm{m}$, while 215 five other samples have $0.8<\mathrm{Mt}<2.3 \mathrm{~A} / \mathrm{m}$, from the above lithologies plus granodiorite (8632) 216 and orthogneiss (240). Other lithologies (metaperidotites, metabasalts, granulite and non 217 itabiritic metasedimentary rocks) have negligible Mt. The strong Mt values are coherent with 218 the susceptibility measurements made by Marsh (1977) on outcrops from the area beneath the 219 large Bangui magnetic anomaly, eastward from our own sampling. Those samples with the 220 largest observed magnetic susceptibilities are itabirites from Bakala ( $k$ around 0.1 SI) and 221 charnockites from Kaga Bandaro ( $k$ around 0.02 SI). We do not elaborate further on Marsh 222 (1977) data obtained using a Bison large coil applied on the outcrops, as their precision and 223 cross-calibration with our more precise data is unknown. 
Bcr $<20$ mT- and two samples (8603 and 240) typical of hematite $-\mathrm{Mrs} / \mathrm{Ms}>0.5, \mathrm{Bcr} / \mathrm{Bc} \approx 1.3$,

227 Bcr>20 mT. Hematite appears multidomain for the itabirite sample (8603) and single domain

228 for the orthogneiss (240). To confirm these identifications, we measured low temperature

229 remanent magnetizations on the two most magnetic samples (Figure 5) and high-temperature

230 susceptibility on the 4 samples showing multidomain magnetite (Figure 6). At low

231 temperature, Morin and Verwey transitions are visible on 8603 and 8576 respectively (Figure

232 5), indicating that pure hematite and pure magnetite are indeed present in these rocks.

233 Magnetite Curie point (at $580^{\circ} \mathrm{C}$; Figure 6) is observed on all samples but in 8603 and 240

234 over $50 \%$ of initial susceptibility remains over $650^{\circ} \mathrm{C}$, indicative of hematite that should carry

235 most of the remanence. For sample 240, this weak residual signal may also correspond to 236 instrument drift, but the previous hysteresis measurements have shown hematite.

237 For surface rock samples, the measured NRM intensities can be biased by the viscous 238 remanent magnetization (VRM) component and other possible spurious unwanted 239 magnetizations, especially lightning induced IRM that can generate anomalously high NRM 240 (Verrier and Rochette, 2002). Therefore we scaled measured NRM with saturation IRM, and 241 computed theoretical in situ NRM intensities from measured SIRM. For samples containing 242 magnetite, we applied a theoretical NRM/SIRM ratio of 2\% (Gattacceca and Rochette, 2004) 243 using a thermo-remanent magnetization (TRM) in the present magnetic field in Bangui. These 244 modelled Mt values are shown in the last column of Table 2. Only two samples exhibit 245 modelled values significantly different from the value computed using our NRM and 246 susceptibility measurements: magnetite-bearing migmatite (8576) and hematite-bearing gneiss 247 (243). For the latter, modelled value is much higher, possibly due to a multicomponent IRM 248 with opposite directions. Measured value for 8576 is 3 times larger than the modelled Mt, 249 suggesting that lightning has biased our NRM measurement, although much larger $250 \mathrm{NRM} / \mathrm{SIRM}$ ratios are commonly observed for samples affected by lightning (Verrier and 
251 Rochette, 2002). An alternative-field demagnetization experiment with REM' ratio computed 252 following Gattacceca and Rochette (2004) does confirm that 8576 NRM is affected by 253 lightning, with REM' peaking at 30\%. For samples containing hematite (8603 and 240), the 254 modelled Mt values (using NRM/SIRM = 50\% after Kletetschka et al., 2000, and Dunlop and 255 Kletetschka, 2001) are similar to the observed ones (30 to 50\%).

Finally, we compare the magnetic properties of our samples with those measured on 257 other rock samples from the Panafrican belt in Cameroon (Figure 7). For West Cameroon 258 Fomopea amphibolites (Njanko et al., 2012; geographic position near 5.5N and 10E), among 25916 sites (with 2 to 4 samples per sites), the maximum $k$ is $910^{-2}$ SI, with $25 \%$ of the sites 260 above $10^{-2}$ SI. In the Nkambé area (6N and 10E), mostly with granitoids but also with 261 accessory amphibolites, the maximum $k$ is $510^{-2} \mathrm{SI}$ in both lithologies, with $16 \%$ of the over 2621200 samples above $10^{-2}$ SI (Fozing et al., in preparation). Rock magnetic measurements, 263 including hysteresis loops and thermomagnetic curves, have been performed on a selection of 26448 samples (Table A2 of the Supplementary Material). They all show a multidomain to large 265 pseudo-single domain magnetite signal. Modelled Mt has been computed after SIRM and 266 susceptibility measurements (Figure 8). Only 15 samples yield values over $1 \mathrm{~A} / \mathrm{m}$, a single 267 one being over $4 \mathrm{~A} / \mathrm{m}$ (at $6.8 \mathrm{~A} / \mathrm{m}$ ). For those strong samples, Q ratio is always over 1 268 (average around 2), stressing again the need to take remanence into account, even for 269 multidomain magnetite. For the East Cameroon study of Kankeu et al. (2009, at 5.5N and 270 14E), the susceptibility of 65 metasediments (schist, quartzite and gneiss) and 18 deformed 271 granites was measured. For these two classes, the maximum $k$ is 2 and $510^{-2}$ SI, with 5 and $27261 \%$ of the samples above $10^{-2}$ SI, respectively. It appears from Figure 7 that the mean magnetic susceptibility distribution is roughly

274 similar regardless of the location in the Panafrican belt, with metamorphic rocks derived from 275 basalts and granites having the strongest magnetic susceptibilities. These histograms confirm 
on a larger scale the conclusion from our samples: no surface lithologies are able to account

277 for the BMA by induced magnetization alone (e.g. Shive, 1989). A review of the extensive 278 magnetic anisotropy work in Panafrican intrusives from NE Brasil (e.g. Archanjo et al., 1995, 279 1998, 2002) confirms this conclusion. When taking into account remanence it appears that 280 magnetite-bearing crustal rocks (granitoids and amphibolite) exceptionally reaches the BMA 281 total magnetization (Figure 8).

\section{6 - Discussion}

These results indicate that a single lithology -hematite-bearing itabirites, i.e. BIF, 285 interstratified with amphibolites and other metasediments- shows strong enough total 286 magnetization $\mathrm{Mt}$ to be the magnetic source of the BMA (Mt $>4.3 \mathrm{~A} / \mathrm{m})$. Lithologies rich in 287 multidomain magnetite (some amphibolites and granites) fail by about a factor 2 to account 288 for the BMA, assuming no significant enhancement of NRM at depth. No magnetic field 289 observations were made at the itabirite sampling locations (LeDonche and Godivier, 1962), 290 but such outcrops should result in a local small-wavelength high-amplitude magnetic field 291 anomalies. Our assumption that the deep crustal lithologies responsible for the BMA could be 292 outcropping over the BMA relies on the possibility that some slices from these deep 293 lithologies have been brought to the surface through orogenic processes (e.g. Rolin, 1991).

294 Our modelling shows that the deep magnetic source seems to be less dense than the deep non295 magnetic surrounding rocks (granulites?), but denser than most of the superficial non296 magnetic formations (quartzites and schists). We also note the numerous reverse faults in this 297 Panafrican belt around Bangui that witness a compressive regime which may have favored the 298 thickening of the iron-rich formations (Figure 1c). 
301 Hemant and Maus (2005) suggested. This metabasalt or amphibolitic part of the Central

302 Africa's lower crust may be the root of the migmatite basement. However, our results also 303 suggest that BIF may compose the source of the BMA because of their magnetization. These 304 rocks are assumed to compose about $25 \%$ of the source of the Kursk magnetic anomaly in 305 Russia (Taylor, 1987; Ravat et al., 1993; Langel and Hinze, 1998). In such case, a positive 306 gravimetric anomaly should be associated to the BMA, as Schmidt et al. (2007) observed on a 307 similar geological formation in Australia (magnetization up to $100 \mathrm{~A} / \mathrm{m}$ ). However as itabirite 308 can be an order of magnitude more magnetized than the BMA source, a volume occupied by a 309 mixture of $10 \%$ itabirite (i.e. a maximum thickness of $2 \mathrm{~km}$ ) and $90 \%$ of low density and less 310 magnetic rock can account for the BMA without inducing a significant excess of mass. As 311 mentioned earlier, a negative gravimetric contrast is associated to the BMA in its central part, 312 but a positive one is found west of Bangui nearby Cameroon border (Boukéké et al., 1995), 313 where a positive magnetic anomaly and itabirites are also observed. Finally, the combination 314 of these two possible magnetic formations (itabirites and amphibolite) may explain the long 315 wavelength and large intensity of the BMA.

316 It is interesting to note that probably all Panafrican metamorphic crustal formations, 317 including these magnetic rocks from the lower crust, may be found on surface today in the 318 Centrafrican Republic, while for other large magnetic anomalies like the Beattie magnetic 319 anomaly in South Africa, the source is from the upper and middle crust but covered by the 320 Karoo basin sediments (Quesnel et al., 2009). Two key points of our interpretation are the 321 possible Curie isotherm -deepened in case of hematite-bearing rocks- in the Central Africa 322 lithosphere, as well as the magnetic mineralogy that carries these strong magnetization 323 intensities at such depth (Frost and Shive, 1986; McEnroe et al., 2004). If it is hematite, our 324 study puts forward a candidate lithology: itabirite or BIF. If it is multidomain magnetite, then 325 the candidate lithology has not been sampled at the surface. It should be two times richer in 
magnetite than the most magnetite-rich granitic and amphibolitic samples studied so far. Such

327 a high Fe amount should correspond to a positive gravity anomaly that is not observed.

328 However, a "homogeneous" tectonic mixing of BIF slices, a few km thick in total, with other

329 metasediments and a few tens of $\mathrm{km}$ thick series of magnetite-rich metamagmatic rocks may

330 be the best solution to account for all geophysical data.

\section{7 - Conclusion}

Using modelling and rock magnetism constraints, we investigated the source of the

334 BMA using samples obtained over the anomaly in Centrafrican Republic, as well as

335 geologically related areas in Cameroon. Modelling implies a total magnetization of the order 336 of $4 \mathrm{~A} / \mathrm{m}$ on a thickness up to $54 \mathrm{~km}$, possibly associated with relatively moderate density of

337 2.87. No surface sample can account for this magnetization based only on induced 338 magnetization. Large enough remanent magnetization intensities are observed for only two 339 surface samples, but lightning has affected one. This highlights the fact that modelled in-situ

340 NRMs based on IRM and magnetic mineralogy may be a more reliable indicator in magnetic 341 anomaly interpretation, compared to NRM actually measured on surface samples, which can 342 yield strongly-biased values with respect to NRM at depth.

343 The only remaining lithology, with $\mathrm{NRM}$ up to $50 \mathrm{~A} / \mathrm{m}$, is hematite-bearing itabirites

344 (BIF) that are Neoproterozoic iron-rich metasediments. Other magmatically-derived

345 lithologies rich in multidomain magnetite (migmatite, amphibolite, granite) can account for 346 only a few $\mathrm{A} / \mathrm{m}$ at most. We suggest that the two types of geological formation may compose 347 the deep crust of this area and particularly the extended deep magnetic source. Further 348 constraints given by drilling or by other geophysical methods like seismics or 349 magnetotellurics are needed to validate (or not) this interpretation and the previously350 published models. Concerning magnetics, new high-resolution ground and airborne magnetic 
351 field measurement surveys will surely improve the characterization of this source, including

352 its possible extensions toward the surface. In the same time, one should benefit from the 353 upcoming SWARM satellite mission (Friis-Christensen et al., 2006) that will allow the use of 354 lateral and vertical magnetic gradients to study such large magnetic anomalies.

356 Acknowledgments

357 The Bangui University is acknowledged for its support to this work, as well as the OSU358 Institut Pytheas. We also thank the two anonymous reviewers who greatly contributed to 359 improve the first state of this manuscript.

\section{References}

363 Almeida, F.F.M., Brito Neves, B.B., de Carneiro, C.D.R., 2000. The origin and evolution of the South American Platform. Earth Sci. Rev., 500, 77-111.

365 Alvarez, P., 1992. Répartition de la sédimentation dans le golfe Protérozoïque supérieur du 366 Schisto-calcaire au Congo et au Gabon: Implications en Afrique centrale. Palaeogeogr.

Alvarez, P., 1995. Evidence for a Neoproterozoic carbonate ramp on the northern of the Central African craton: relations with the Late Neoproterozoic troughs. Rundschau, $84,636-648$

371 Alvarez, P., 1999. Un segment proximal de rampe carbonatée d'âge protérozoïque supérieur au Nord du craton d'Afrique Centrale (Sud-Est de la République Centrafricaine). J. Afr. Earth Sci., 23, 263-266. 
374 Archanjo, C.J., Launeau, P., Bouchez, J.-L., 1995. Magnetic fabric vs. magnetite and biotite shape fabrics of the magnetite-bearing granite pluton of Gameleiras (Northeast Brazil). Phys. Earth Planet. Int., 89, 63-75.

Archanjo, C.J., Macedo, J.W.P., Galindo, A.C., Araujo, M.G.S., 1998. Brasiliano crustal extension and emplacement fabrics of the mangerite-charnockite pluton of Umarizal, North-east Brazil. Precambr. Res., 87(1-2), 19-32.

Ferré, E., Dereris, J., Bouchez, J.L., Lar, A.U., Peucat, J.J., 1996. The Pan-African Sci. Paris, 262, D, 1046-1049.

Boukéké, D.-B., Legeley-Padovani, A., Poudjom-Djomani, Y.-H., Foy, R., Albouy, Y., 1995. Gravity map of Central African Republic: Bouguer anomalies. ORSTOM, Institut français de recherche scientifique pour le développement en coopération. Carte 1/6000000, Lever gravimétrique de reconnaissance.

De, S., Heaney, P.J., Hargraves, R.B., Vicenzi, E.P., Taylor, P.T., 1998. Microstructural observations of polycristalline diamond: a contribution to the carbonadro conundrum. Earth Planet. Sci. Lett., 164, 421-433.

Dunlop, D.J., Kletetschka, G., 2001. Multidomain hematite: A source of planetary magnetic anomalies?. Geophys. Res. Lett., 28, 3345-3348.

reactivation of Eburnean and Archean provinces in Nigeria: structural and isotopic data. J. Geol. Soc. London, 153, 719-728. 
Feybesse, J.L., Johan, V., Triboulet, C., Guerrot, C., Mayaga-Mikolo, F., Bouchot, V., Eko Ndong, J., 1998. The West Central African belt: a model of 2.5-2.0 Ga accretion and two-phase orogenic evolution. Precambr. Res., 87, 161-216.

Finlay, C.C., Maus, S., Beggan, C.D., Bondar, T.N., Chambodut, A., Chernova, T.A., Chulliat, A., Golovkov, V.P., Hamilton, B., Hamoudi, M., Holme, R., Hulot, G., Kuang, W., Langlais, B., Lesur, V., Lowes, F.J., Lühr, H., Macmillan, S., Mandea, M., McLean, S., Manoj, C., Menvielle, M., Michaelis, I., Olsen, N., Rauberg, J., Rother, M., Sabaka, T.J., Tangborn, A., Tøffner-Clausen, L., Thébault, E., Thomson, A.W.P., Wardinski, I., Wei, Z. and Zvereva, T.I., 2010. International Geomagnetic Reference Field: the eleventh generation. Geophys. J. Int., 183, 1216-1230.

Friis-Christensen, E., Lühr, H., Hulot, G., 2006. Swarm: A constellation to study the Earth's magnetic field. Earth Planets Space, 58, 351-358.

Frost, B.R., Shive, P.N., 1986. Magnetic mineralogy of the lower continental crust. J. Geophys. Res., 91, 6513-6522.

Gattacceca, J., Rochette, P., 2004. Toward a robust paleointensity estimate for meteorites. Earth Planet. Sci. Lett., 227, 377-393.

Gérard, G., 1958. Carte géologique de l'Afrique Equatoriale Française au 1/2000000. Notice explicative. Pub. DGM AEF.

Girdler, R.W., Taylor, P.T., Frawley, J.J., 1992. A possible impact origin for the Bangui magnetic anomaly (central Africa). Tectonophysics, 212, 45-58.

Gorshkov, A.I., Titkov, S.V., Pleshakov, A.M., Sivtsov, A.V., Bershov, L.V., 1996. Inclusions of native metals and other mineral phases into Carbonado from the Ubangi Region (Central Africa). Geology of Ore Deposits, 38, 114-119. 
Hemant, K., Maus S., 2005. Geological modeling of the new CHAMP magnetic anomaly maps using a geographical information system technique. J. Geophys. Res., 110, B12103, 1-23.

Kankeu, B., Greiling, R.O., Nzenti, J.P., 2009. Pan-African strike-slip tectonics in eastern Cameroon-Magnetic fabrics (AMS) and structure in the Lom basin and its gneissic basement. Precambr. Res., 174, 258-272.

Kennedy, W.Q., 1964. The structural differenciation of Africa in the Panafrican (+/- 500 millions years) tectonic episode. $8^{\text {th }}$ ann. Rep. Res. Inst. afro Geal. Leeds Univ., U.K., 48-49.

Kletetschka, G., Wasilewski, P.J., Taylor, P.T., 2000. Unique thermoremanent magnetization of multidomain-sized hematite: Implications for magnetic anomalies. Earth Planet. Sci. Lett., 176, 469-479.

Koeberl, C., 1998. Identification of meteoritical components in impactites. In: M.M. Grady, R. Hutchison, G.H.J. McCall, D.A. Rothery (Editors). Meteorites: Flux with Time and Impact Effects. Geol. Soc. London, Spec. Publ., 140, 133-152.

Langel, R.A., Hinze, W.J., 1998. The magnetic field of the Earth's lithosphere: the satellite perspective. Cambridge University Press, 429 p.

LeDonche, L., Godivier, R., 1962. Réseau magnétique ramené au $1^{\text {er }}$ janvier 1956 : République Centrafricaine, Tchad méridional. ORSTOM, Office de la recherche scientifique et technique outre mer, cartes 1/2500000, Cahiers ORSTOM / Géophysique, No 1.

Marsh, B.D., 1977. On the origin of the Bangui magnetic anomaly, Central African Empire, NASA Report, $63 \mathrm{p}$.

Maus, S., Yin, F., Lühr, H., Manoj, C., Rother, M., Rauberg, J., Michaelis, I., Stolle, C., Müller, 2008. Resolution of direction of oceanic magnetic lineations by the sixth- 
generation lithospheric magnetic field model from CHAMP satellite magnetic measurements. Geochem. Geophys. Geosyst., 9, Q07021, doi:10.1029/2008GC001949.

448 McEnroe, S.A., Langenhorst, F., Robinson, P., Bromiley, G., Shaw, C., 2004. What's magnetic in the lower crust?. Earth Planet. Sci. Lett., 226, 175-192.

450 Mestraud, J.L., 1971. Afrique centrale. In: Tectonique de l'Afrique. UNESCO, Paris, 461-507.

451 Nickles, M., 1952. Les formations géologiques de la cuvette tchadienne. In: Rapport de la commission scientifique du Logone et du Tchad. Paris, 13p.

453 Njanko, T., Fozing, E.M., Kwékam, M., Yakeu Sandjo, A.F., Njonfang, E., 2012. Magnetic characterization of amphibolite from the Fomopéa pluton (West Cameroon): their implication in the Pan-African deformation of the central african fold belt. Acta Geologica Sinica, 86, 1, 73-84.

Penaye, J., Toteu, S.F., Tchameni, R., Van Schmus, W.R., Tchakounté, J., Ganwa, A., Minyem,

Pin, C., Poidevin, J.L., 1987. U-Pb Zircon evidence for a Pan-African granulite facies metamorphism in the central African Republic: A new interpretation of the high-grade series of the northern border of the Congo craton. Precambr. Res., 36, 303-312.

Poidevin, J.L., 1991. Les ceintures de roches vertes de la République Centrafricaine (Mbomou, Bandas, Boufoyo, Bogoin): contribution à la connaissance du Précambrien du Nord du craton du Congo. PhD Thesis, Sci.Univ. Clermont-Ferrand, 440p. 
Ravat, D.N., 1989. Magsat investigations over the greater African region. Ph.D. Thesis, Purdue University.

471 Ravat, D.N., Hinze, W.J., Taylor, P.T., 1993. European tectonic features observed by Magsat. Tectonophysics, 220, 157-173.

473 Ravat, D., Wang, B, Wildermuth, E., Taylor, P.T., 2002. Gradients in the interpretation of satellite-altitude magnetic data: an example from central Africa. J. Geodyn., 33, 131142.

Regan, R. D., Marsh, B.D., 1982. The Bangui magnetic anomaly: Its geological origin. J. Geophys. Res., 87, 1107-1120. Africain. Coll. Int. Géochronol., Nancy Sci.Terre, X, 461-478.

Rochette, P., Gattacceca, J., Chevrier, V., Hoffmann, V., Lorand, J.P., Funaki, M., Hochleitner, R., 2005. Matching Martian crustal magnetization and meteorite magnetic properties. Meteorit. Planet. Sci, 40, 529-540.

Rolin, P., 1995a. Carte tectonique et géologique de la République Centrafricaine au 1/1.000000, ORSTOM.

Rolin, P., 1995b. La zone de décrochements panafricains des Oubanguides en République Centrafricaine. C.R. Acad. Sci. Paris, 320, IIa, 63-69.

490 Schmidt, P.W., McEnroe, S.A., Clark, D.A., Robinson, P., 2007. Magnetic properties and potential field modeling of the Peculiar Knob metamorphosed iron formation, South Australia: An analog for the source of the intense Martian magnetic anomalies?. J. Geophys. Res., 112, b03102-b004495. 
494 Shive, P.N., 1989. Can remanent magnetisation in the deep crust contribute to long 495 wavelength magnetic anomalies?. Geophys. Res. Lett., 16, 89-92.

496 Taylor, P.T., Frawley, J.J., 1987. Magsat anomaly data over the Kursk region, U.S.S.R. Phys. 497 Earth Planet. Inter, 45, 255-265.

498 Toteu, S.F., Van Schmus, W.R., Penaye, J., Michard, A., 2001. New U-Pb, and Sm-Nd data 499 from North-central Cameroon and its bearing on the pre-Pan-African history of central $500 \quad$ Africa. Precambr. Res., 108, 45-73.

501 Verrier, V., Rochette, P., 2002. Estimating peak currents at Ground Lightning Impact using 502 Remanent Magnetization. Geophys. Res. Lett., 29, 10.1029/2002GL015207. 


\section{Figure captions}

517 Figure 1: Location (a), regional (b) and local (c) geological contexts of the studied area. In

518 (a), the black rectangle and disks correspond to the sampled areas in Centrafrican Republic

519 and Cameroon, respectively. The dotted-dashed line delineates the coastline of South

520 America, translated and rotated next to Africa. A zoom is shown in (b) where the relationships

521 between the different Archean blocks are reconstituted. Zone A corresponds to the

522 Paleoproterozoic rocks with Archean inheritances underlining the border of the mega-Congo

523 craton. Zone $\mathrm{B}$ are the Pan-African rocks with Paleoproterozoic inheritances. Zone C

524 represents the nappes of the $600 \mathrm{Ma}$ Central African Belt. Zone D corresponds to the

525 Mesozoic sediments of the Benue trough and Zone E are the oceanic rocks. PF, Pernambuco 526 fault; ADF, Adamawa fault; TBF, Tchollire-Banyo fault; dotted-dashed lines: reconstituted

527 South America (SW one) and Africa (NE one) coastlines. This (b) regional map is modified 528 from Penaye et al. (2004), Poidevin (1991), Ferré et al. (1996), Feybesse et al. (1998), 529 Almeida et al. (2000) and Toteu et al. (2001). The dashed rectangle corresponds to the 530 Centrafrican sampled area (c), while the black disks show the approximate locations of the 531 sampled areas in Cameroon. In (c), modified from Rolin (1995a), details about the surface 532 lithology and the structural features of the studied area nearby Bangui are shown. 1, Archean 533 gneissic basement; 2, Paleoproterozoic migmatitic domain; 3, Lower-Neoproterozoic domain 534 with (a) quartzites and (b) itabirites; 4, Upper-Neoproterozoic schists; 5, Upper535 Neoproterozoic limestones/marbles; 6, Panafrican Gbayas Nappe with orthogneisses, 536 granulites and granites; 7, Post-Panafrican cover with sandstones and clays. Black filled 537 circles with names indicate the sampling sites. 
539 Figure 2: Interpolated magnetic anomaly maps near the surface over Centrafrican Republic 540 and Chad. On left, gridded data from the satellite MF7 model (derived from Maus et al. 541 (2008) downward continued to $2.5 \mathrm{~km}$ of altitude). On right, ground magnetic data 542 interpolated from LeDonche and Godivier (1962). The solid lines correspond to the selected 543 profiles for modelling, while the rectangle indicates the location of Figure 1c.

545 Figure 3: Crustal magnetic models (bottom panels) along the NW-SE western (a) and eastern (b) profiles (top panels) shown on Figure 2. Sat, satellite-derived magnetic data; Ground, 547 ground magnetic data; Gravi, ground gravity data (Boukéké et al., 1995); Obs, observations, 548 Pred, predictions. For models, layer density and magnetization properties are represented by 549 the filling color and/or pattern (see Table 1 for details). Formation 1 has a total magnetization 550 intensity (Mt) of $4.3 \mathrm{~A} / \mathrm{m}$, which corresponds to the best model with this source geometry (see Supplementary Material).

Figure 4: Hysteresis curves (specific magnetization) of four samples. Bc, coercitive field; Ms, 554 saturation magnetization; Mrs, remanent magnetization at saturation; Bcr, coercitive field of 555 the remanent magnetization, derived from the back-field curve.

557 Figure 5: Low-temperature remanent magnetization (RM) curves for two samples (cooling and subsequent heating of a room temperature IRM), showing the Verwey (in a) and Morin (in b) transitions. For (b) is also shown the induced magnetization (IM) heating and cooling curves, measured in a $0.3 \mathrm{~T}$ field.

562 Figure 6: Effect of heating (black) and cooling (gray) on the normalized magnetic 563 susceptibility of the same four samples as in Figure 4. 
565 Figure 7: Histogram (in logarithmic representation) of $k_{m}$, the mean magnetic susceptibility, 566 for Cameroon and Centrafrican Republic (CR) rock samples.

568 Figure 8: Histogram of modelled total magnetization (Mt) derived from IRM and 569 susceptibility measurements on Panafrican magnetite-bearing rocks from Cameroon (black) 570 and Centrafrican Republic (white). 
Figure 1 revised

Click here to download high resolution image

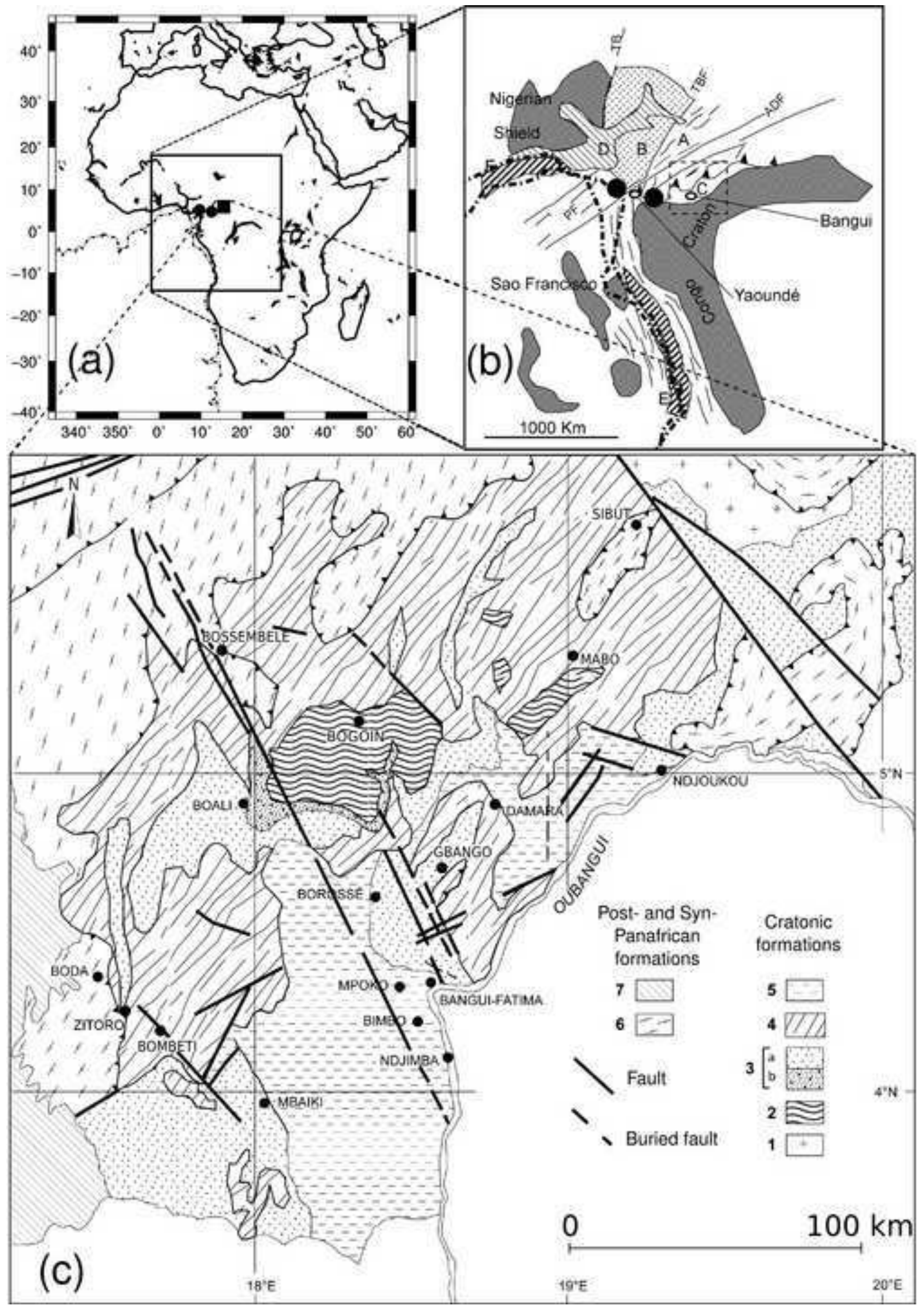



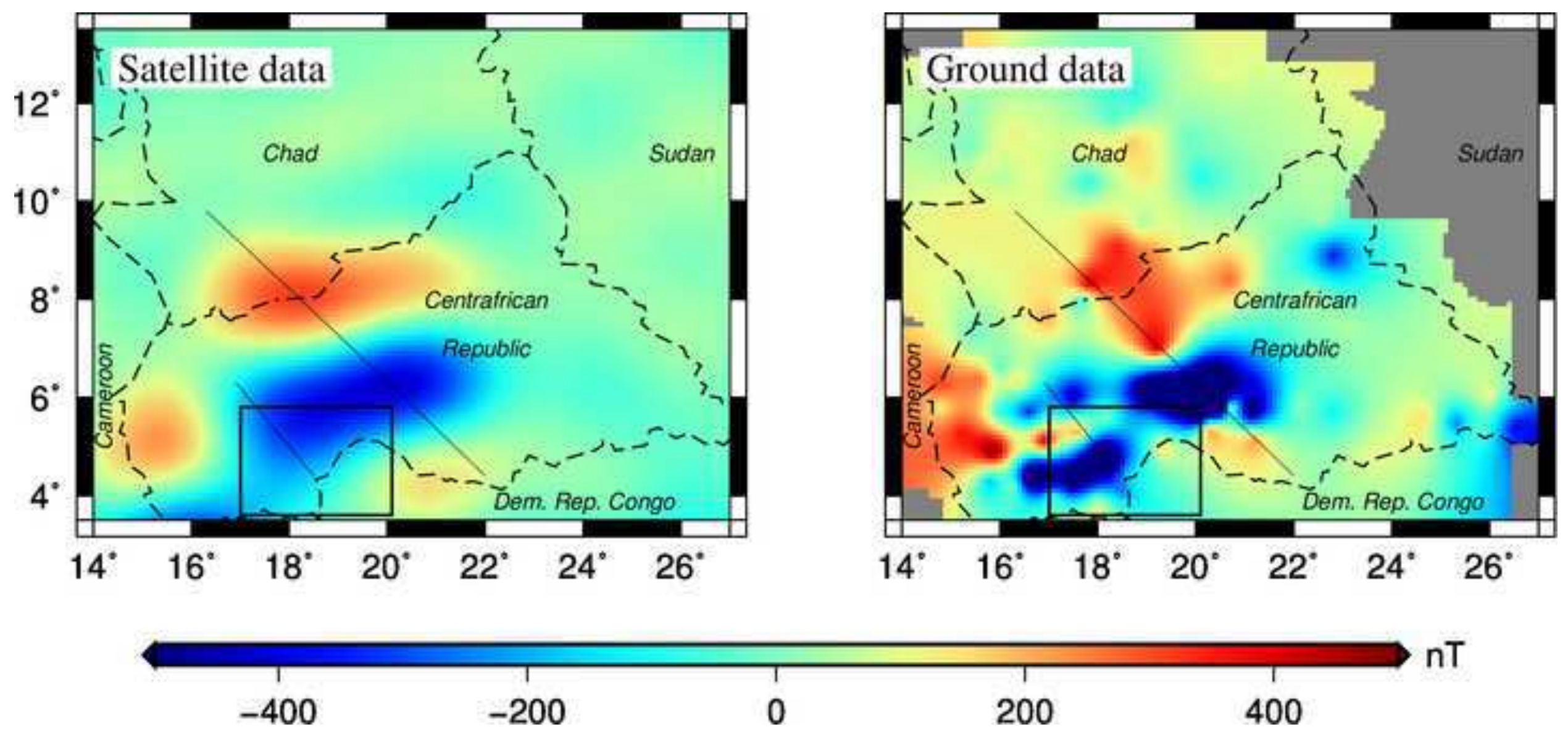
(a) Western profile

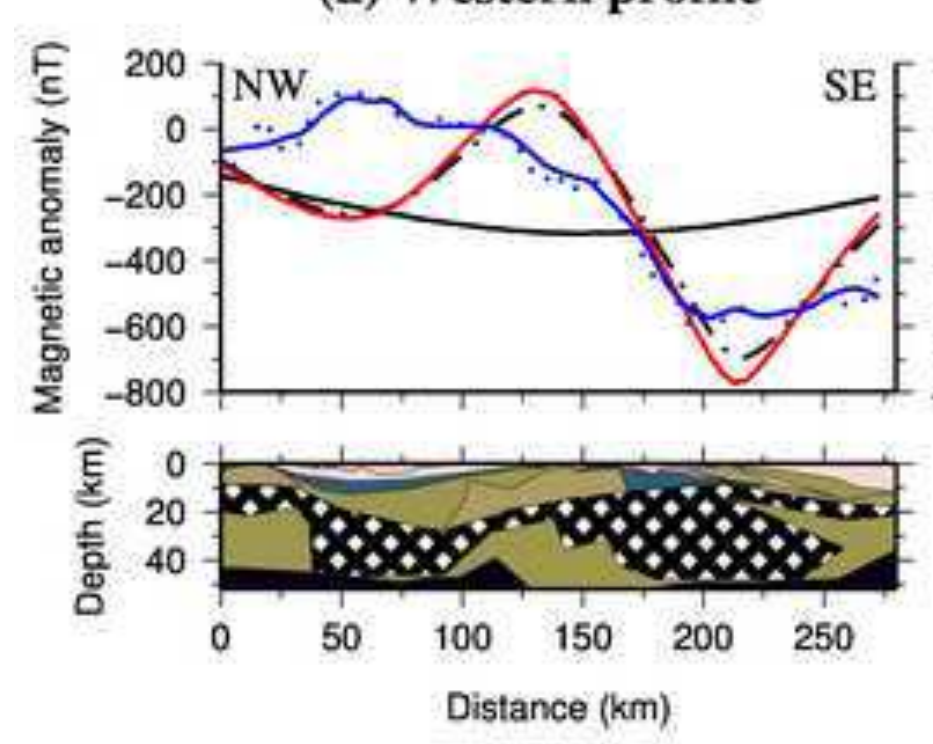

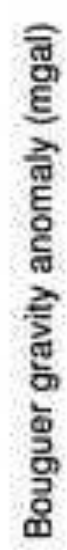

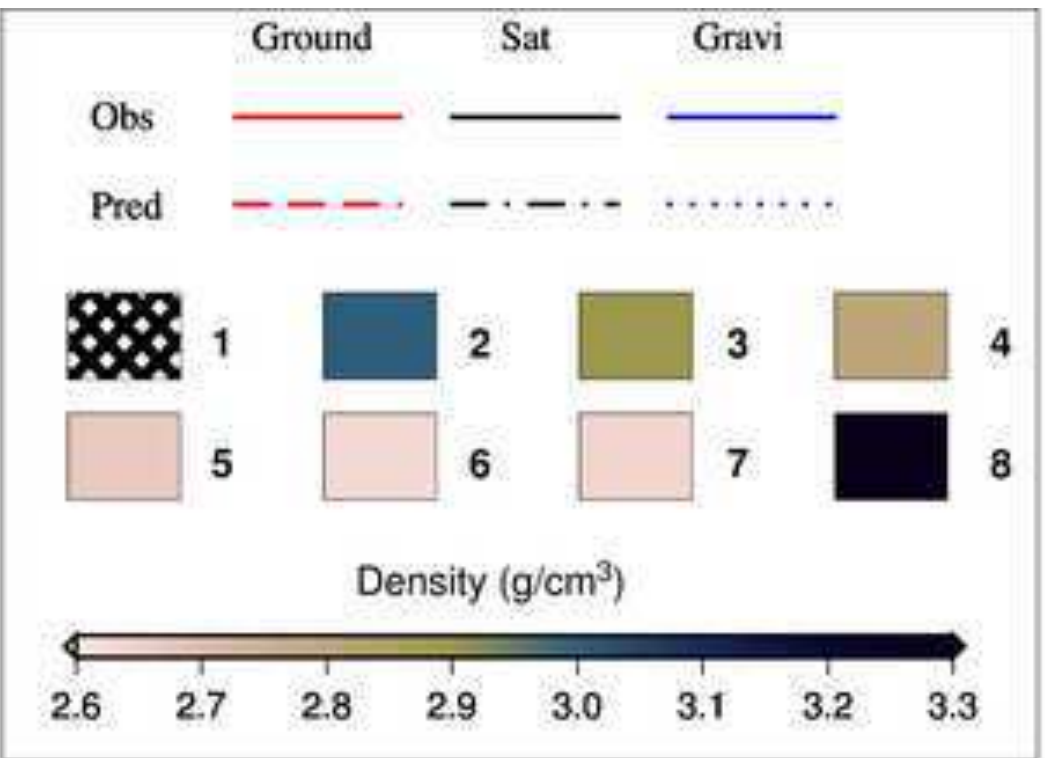

(b) Eastern profile

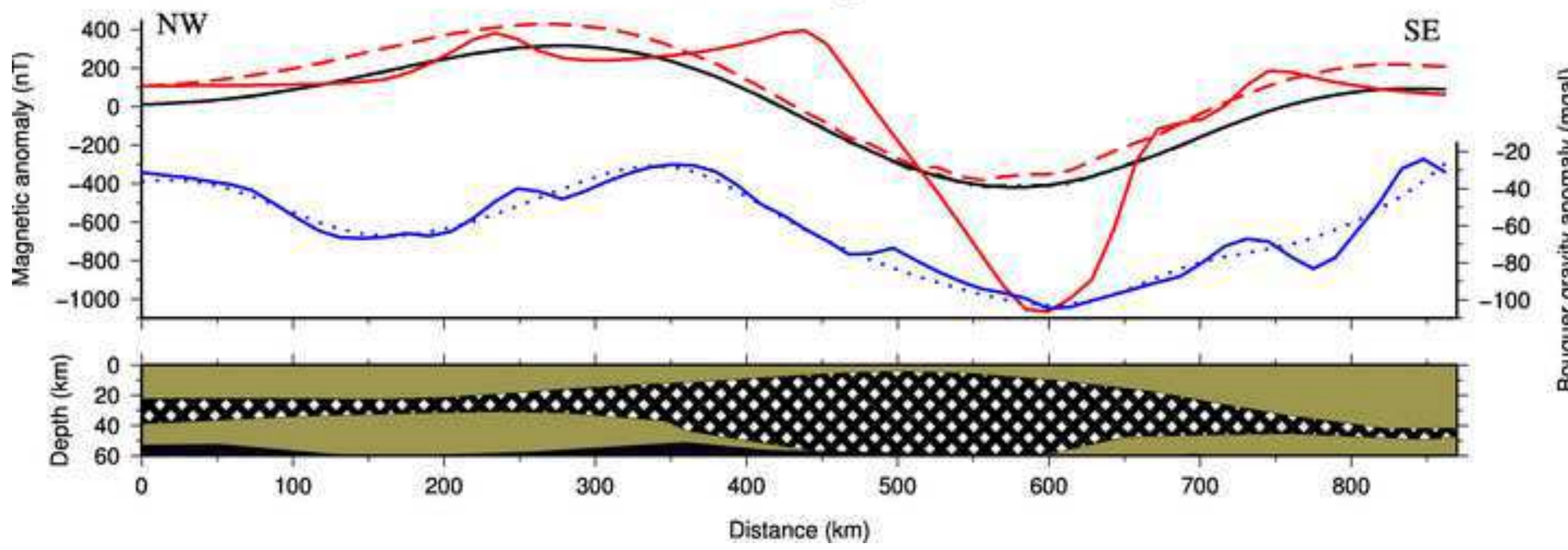


Click here to download high resolution image
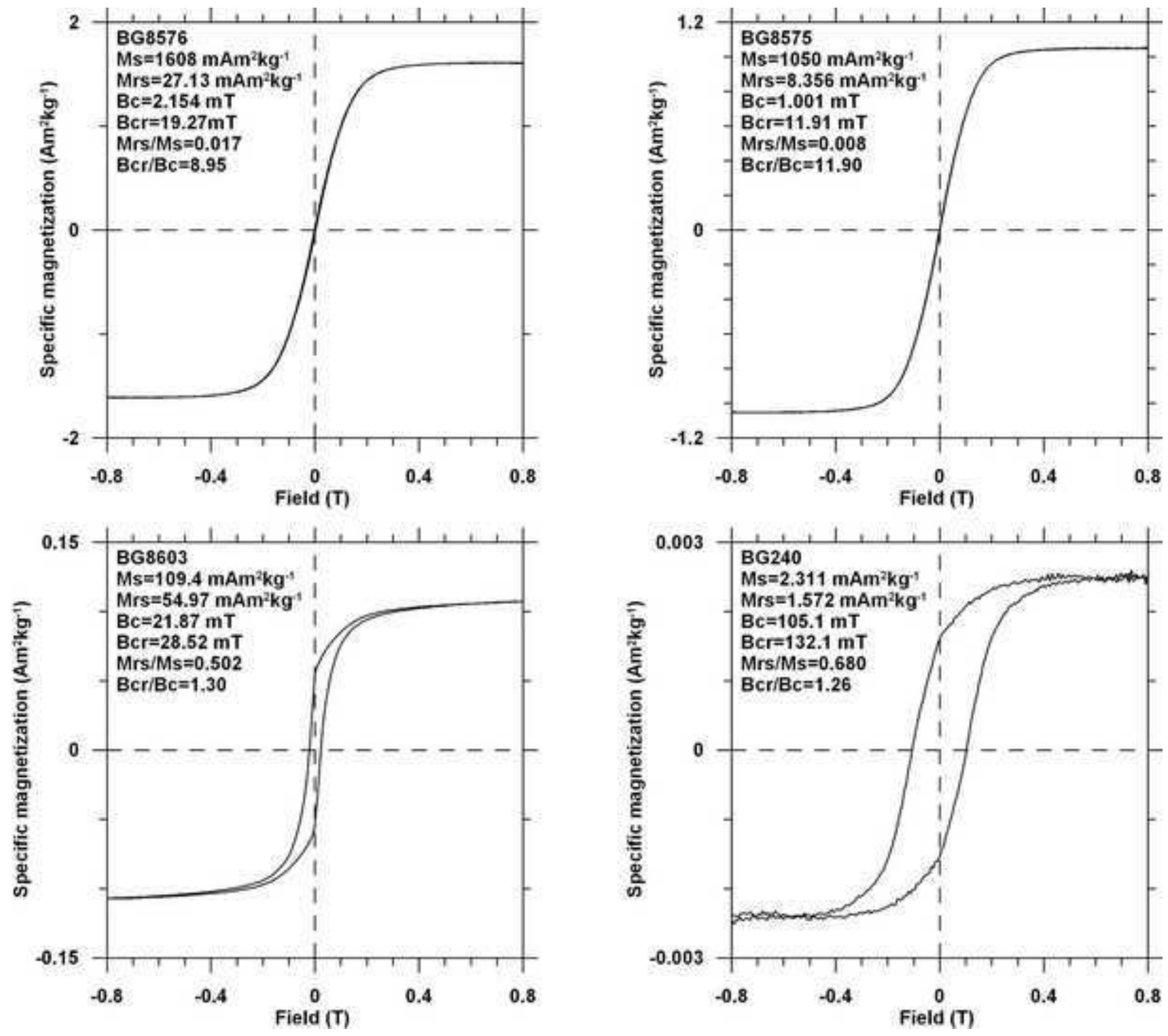
Figure 5 revised

Click here to download high resolution image
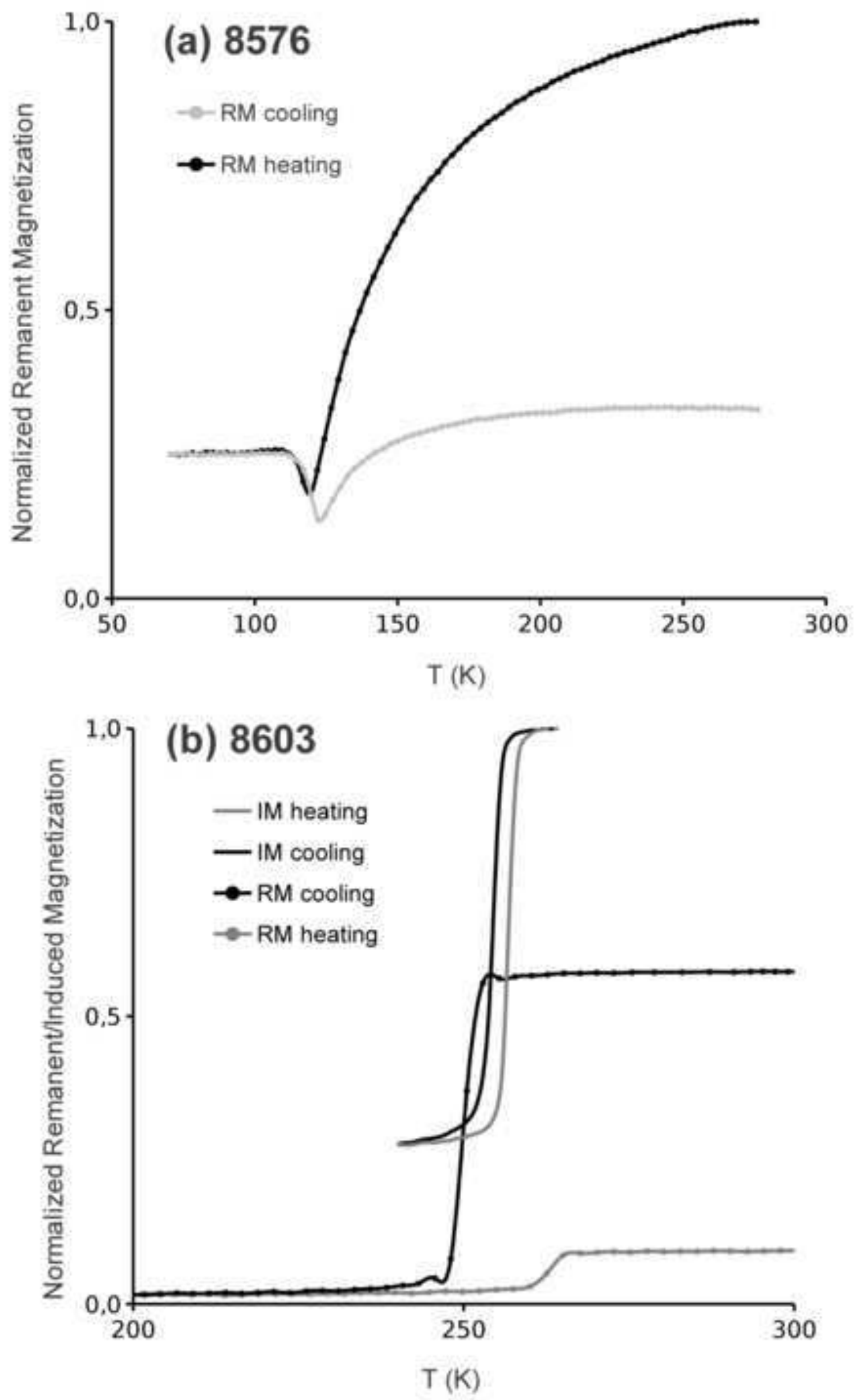

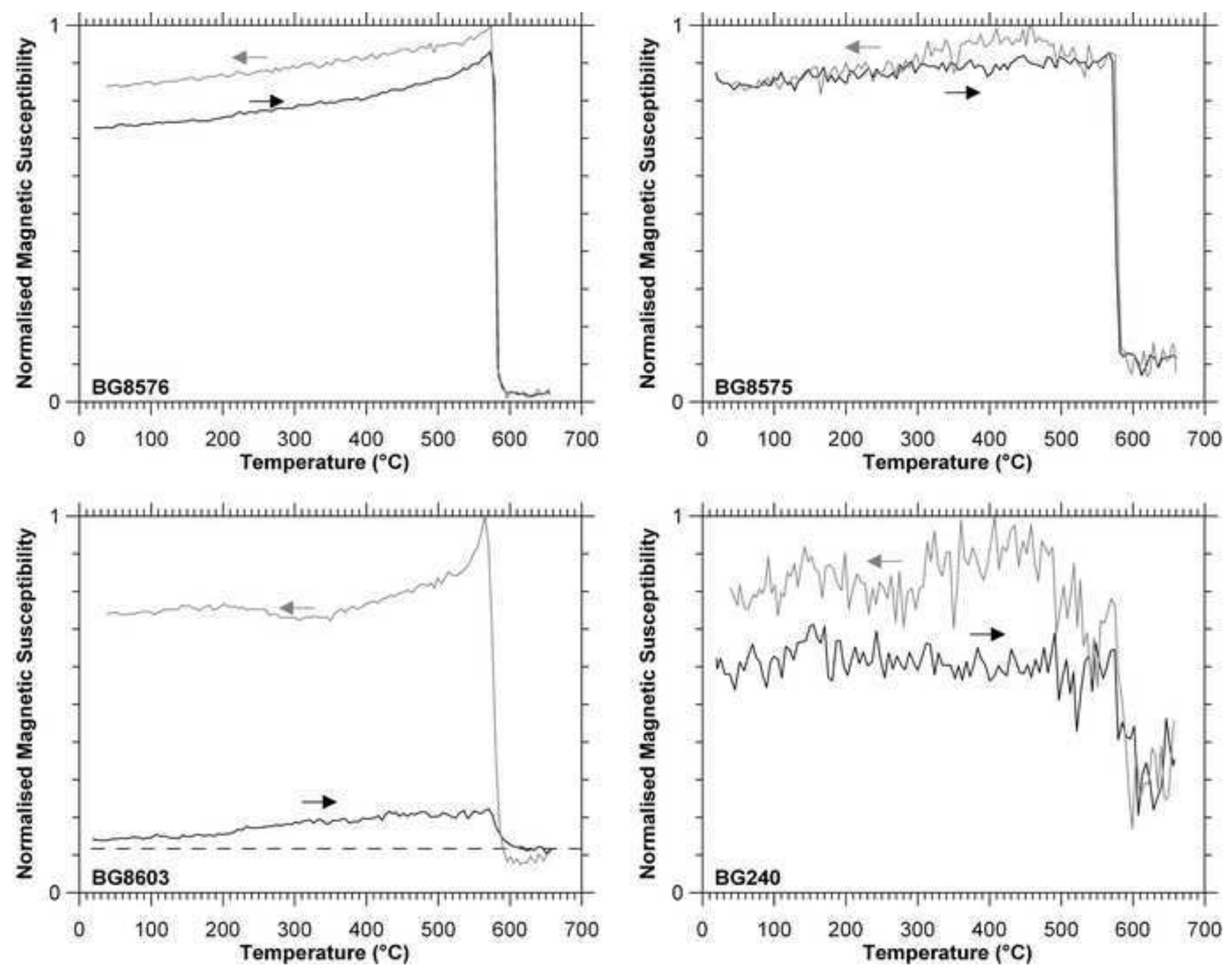


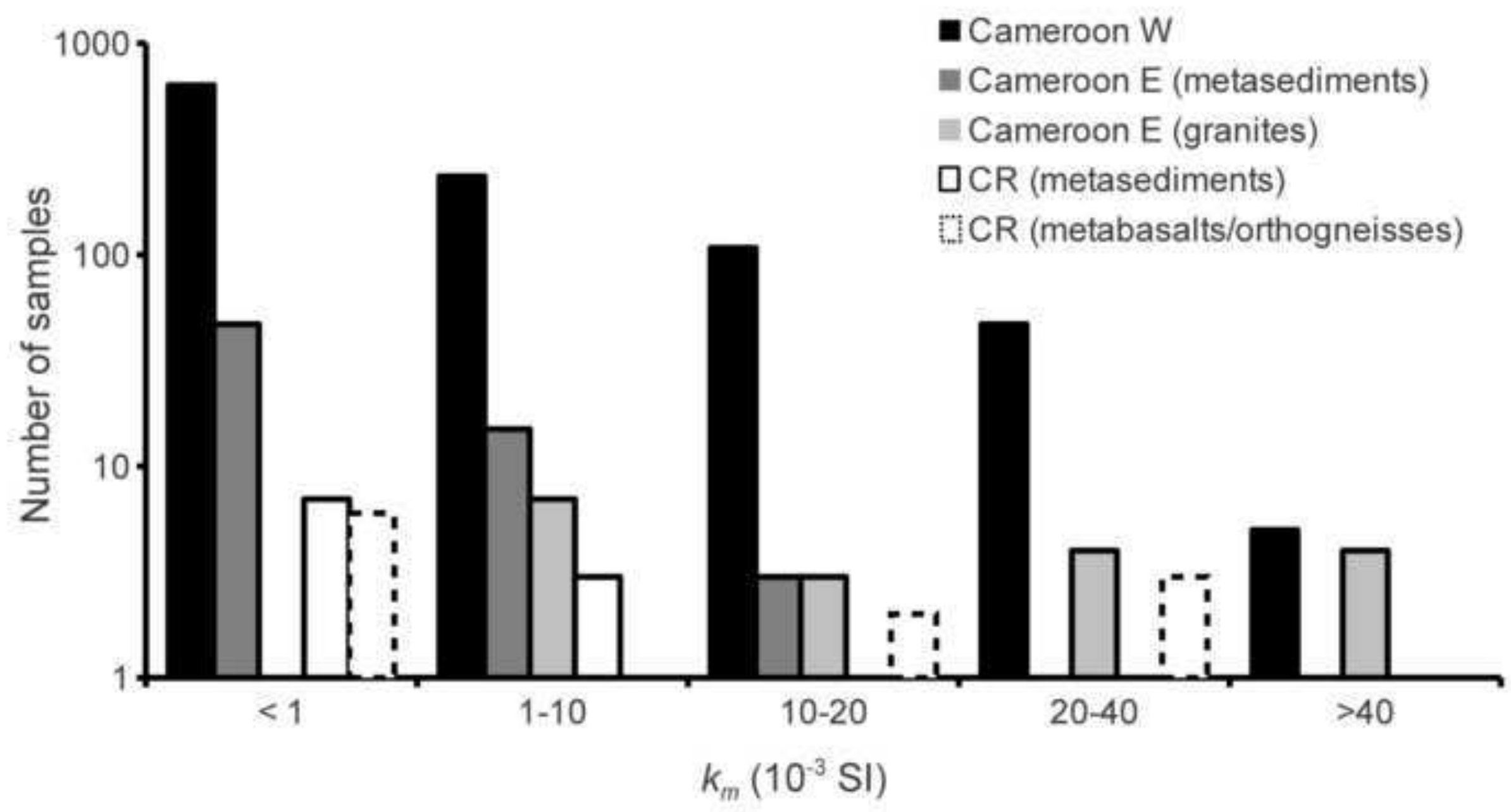




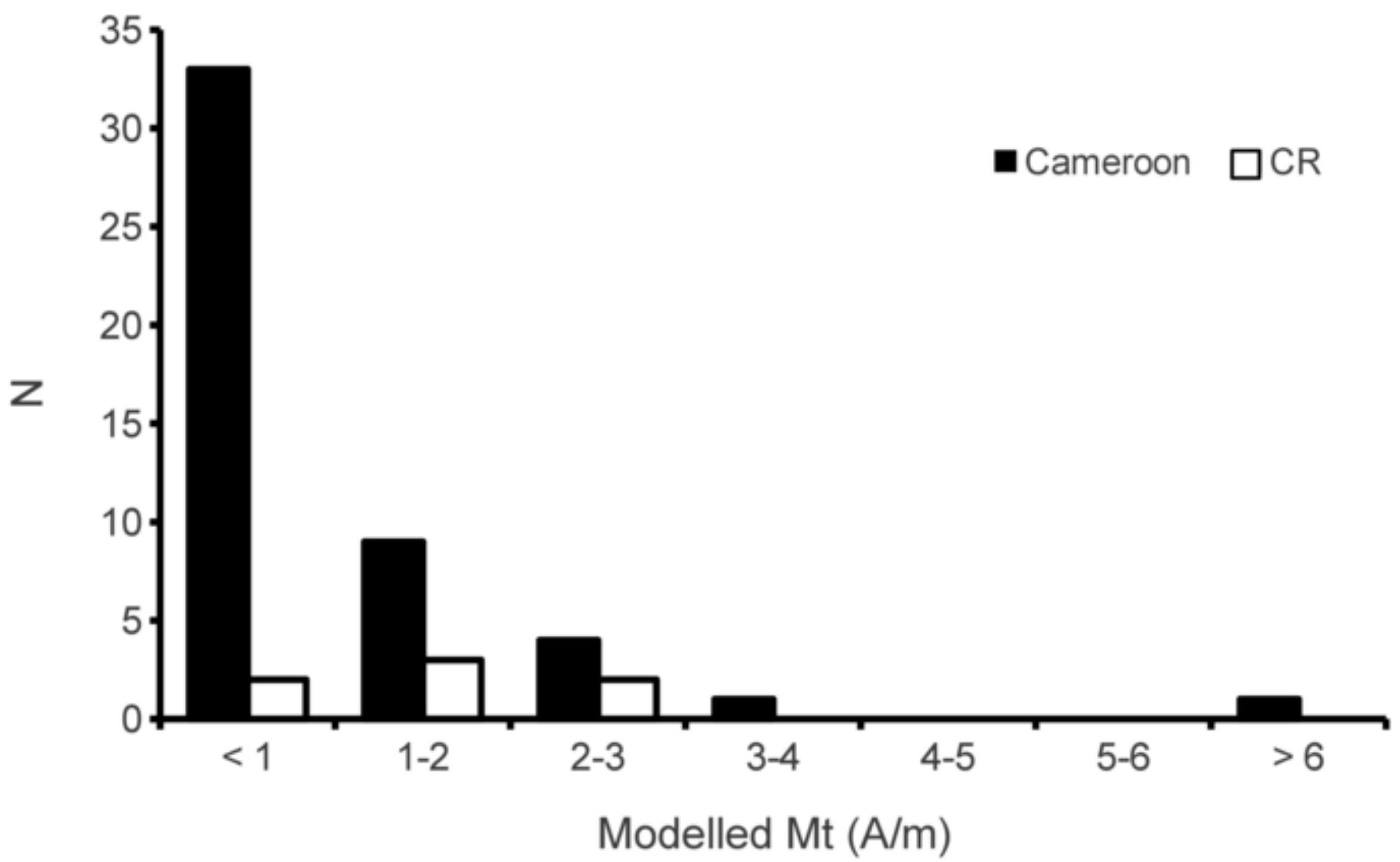


1 Table 1. Magnetization* and density contrasts of the best models for the source of the BMA.

$\begin{array}{ccccc} & k & \mathrm{NRM} & \mathrm{d} & \text { Rock type**** } \\ \text { Layer }^{* *} & \left(10^{-3} \mathrm{SI}\right) & (\mathrm{A} / \mathrm{m}) & \left(\mathrm{g} . \mathrm{cm}^{-3}\right) & \end{array}$

\begin{tabular}{ccccc}
\hline 1 & 10 & 4.0 & 2.870 & Magnetic source layer \\
2 & 1 & - & 3.000 & Metabasalt \\
3 & 1 & - & 2.900 & Granulite/Orthogneiss \\
4 & 1 & - & 2.850 & Amphibolite \\
5 & 1 & - & 2.665 & Quartzite \\
6 & 1 & - & 2.630 & Schist \\
7 & 1 & - & 2.640 & Panafrican nappe \\
8 & - & - & 3.300 & Mantle rocks
\end{tabular}

2 *all layers have their magnetization oriented in the $1960\left(\mathrm{I}=-14.5^{\circ}, \mathrm{D}=-5^{\circ}\right)$ and $2011\left(\mathrm{I}=-16.76^{\circ}, \mathrm{D}=0.3^{\circ}\right)$

3 magnetic field directions in Bangui for the modelling of the ground and satellite magnetic data, respectively.

$4 * *$ see correspondance in Figure 3.

$5 * * *$ these rock types are expected with regards as their densities, their magnetization properties and the surface

6 geology. 
1 Table 2. Magnetic properties of rock samples from the Bangui area.

\begin{tabular}{|c|c|c|c|c|c|c|c|c|}
\hline & & & & & & & Laboratory & \\
\hline Lithology & ID & $\begin{array}{c}\mathrm{X} \\
\left(10^{-9} \mathrm{~m}^{3} \cdot \mathrm{kg}^{-1}\right)\end{array}$ & $\begin{array}{c}\text { NRM } \\
\left(\text { A. } \mathrm{m}^{2} \cdot \mathrm{kg}^{-1}\right)\end{array}$ & $\begin{array}{c}\mathrm{Mt} \\
(\mathrm{A} / \mathrm{m})\end{array}$ & Q & $\begin{array}{c}\text { NRM/SIRM } \\
(\%)\end{array}$ & $\begin{array}{c}\text { modelled } \\
\mathrm{Mt}\end{array}$ & Sampling site \\
\hline & & & & & & & $(\mathrm{A} / \mathrm{m})$ & \\
\hline Itabirite & 8603 & 798 & 23856.2 & 76.4 & 1117.8 & 43.6 & 88.1 & Bogoin \\
\hline & 243 & 629 & 237.5 & 0.8 & 14.1 & 5.1 & 7.5 & Bogoin \\
\hline Migmatite & 8576 & 12201 & 2041.1 & 6.4 & 6.3 & 7.6 & 2.3 & Mabo \\
\hline & 8575 & 8496 & 66.0 & 0.8 & 0.3 & 0.7 & 1.1 & Mabo \\
\hline Orthogneiss & 240 & 85 & 833.8 & 2.3 & 365.5 & 53.1 & 2.1 & Mabo \\
\hline & 234 & 229 & 342.8 & 0.9 & 55.9 & 36.1 & 1.5 & Sibut \\
\hline & 235 & 5165 & 102.7 & 0.7 & 0.7 & 3.4 & 0.5 & Sibut \\
\hline & 216 & 23 & 0.9 & 0.0 & 1.4 & - & - & Galabadjia \\
\hline Granodiorite & 8632 & 7587 & 382.9 & 1.6 & 1.9 & 1.6 & 1.8 & $\mathrm{LaMbi}$ \\
\hline Metaperidotite & 8840 & 5223 & 76.7 & 0.6 & 0.5 & 0.8 & 0.9 & $\mathrm{LaMbi}$ \\
\hline & 8838 & 1235 & 105.6 & 0.4 & 3.2 & - & - & La Mbi \\
\hline & 8836 & 164 & 3.0 & 0.0 & 0.7 & - & - & Sibut \\
\hline Quartzite & 203 & 1902 & 82.7 & 0.4 & 1.6 & - & - & Boali \\
\hline & 8564 & 5 & 1.4 & 0.0 & 11.0 & - & - & Bossembélé \\
\hline & 213 & 7 & 0.8 & 0.0 & 3.8 & - & - & Mbalki \\
\hline & 452 & 20 & 0.4 & 0.0 & 0.7 & - & - & Ouango \\
\hline Granulite & 230 & 304 & 38.8 & 0.1 & 4.8 & - & - & Sibut \\
\hline Metabasalt & 8602 & 292 & 0.2 & 0.0 & 0.0 & - & - & Bogoin \\
\hline Micaschist & 249 & 171 & 2.2 & 0.0 & 0.5 & - & - & Boali \\
\hline Metasilexite & 217 & 52 & 1.3 & 0.0 & 0.9 & - & - & Kamaro \\
\hline
\end{tabular}


Cipolin

8631

0.4

0.0

$-11.9$

Fatima

8610

0.4

0.0

$-13.0$

Ndjimba 
